\title{
Pro-business and Pro-Market Reforms in Pakistan: Economic Growth and Stagnation 1950-51 to 2011-12
}

\author{
Dr Grace Kite \\ Save the Children \\ G.Kite@savethechildren.org.uk
}

And

\section{Professor Matthew McCartney \\ School of Interdisciplinary Area Studies, University of Oxford \\ Matthew.McCartney@area.ox.ac.uk}

This paper uses a new method to analyse the causes of growth and stagnation in Pakistan between 1950-51 and 2011-12. It provides support for the argument that pro-business reforms have been an important driver of Pakistan's economic growth. This result holds across two episodes of growth and one episode of stagnation. These findings lead to a clear policy implication: if Pakistan is to return to fast growth, policy needs to move away from pro-market reforms, learn these lessons of history, and promote the profitability of business to incentivise private investment and so boost economic growth. 


\section{Introduction}

The more that is understood about economic growth, the less Pakistan seems able to achieve it. The seminal 1991 work by Robert Barro initiated a flood of empirical studies of growth. Ten years later Brock and Durlauf (2001) looked back to econometric research that by then had identified more than ninety determinants of economic growth. Since that review there have been improvements in the techniques of testing and also a focus on the deeper determinants of growth such as geography, institutions, and culture. In Pakistan, this renaissance in understanding has coincided with the rapid growth rates experienced from the 1960s to the 1980s giving way to ever-slowing growth starting around 1992-93 ${ }^{1}$. Between 2007-08 and 2011-12, Pakistan's GDP growth averaged only 3.1\% p.a. (State Bank of Pakistan, 2012).

Existing studies of economic growth in Pakistan revolve around two approaches: econometrics and the case study. To date there have been few efforts to combine or reconcile these two approaches, it is this gap that this paper seeks to partially fill. Our method uses rigorous statistical techniques to select episodes of growth and stagnation for an in-depth case study analysis. The results in this paper provide significant support for the view that pro-business reforms centred on boosting profits and investment are an important driver of economic growth in Pakistan. This holds across two episodes of growth when pro-business reforms were implemented (195152 to 1960-61) and maintained (1961-62 to 1991-92), and one episode of stagnation (1992-93 to 2011-12) when such reforms were undermined.

This paper is organised as follows. Section 2 reviews other studies of economic growth in Pakistan, section 3 runs through the empirical method used to derive the three case studies of growth discussed in this paper, section 4 introduces the theoretical model for the paper - the pro-market vs pro-business distinction, sections 5 to 7 discuss the three case studies in relation to the two theoretical models and section 8 concludes.

\section{Previous studies of economic growth in Pakistan}

The study of economic growth in Pakistan can be divided into two distinct methodological camps. The first is a body of econometric analysis that regresses the dependent variable (GDP growth) on various independent variables identified as being important by theory. This method has its origins in Barro (1991). Across a broad cross-section of countries Levine and Renelt (1992) found that investment is the only variable robustly related to GDP growth. The econometric evidence for Pakistan echoes this finding. Total investment (Khan et al, 2005; Iqbal and Zahid, 1998), private sector investment (Ghani and ud-Din, 2006); physical and human capital investment (Atique et al 2004; Iqbal and Zahid, 1998); and foreign direct investment (FDI) (Ahmad et al, 2003) are found to have a positive impact on GDP. Other 'obvious' causes of economic growth in Pakistan such as education show little or even a negative relationship with growth (Khan 2005; Iqbal and Zahid 1998). The Pakistan econometrics literature has incorporated both progress in statistical methods

${ }^{1} 1992-93$ denotes the financial year from 1 July 1992 to 31June 1993. This convention is adopted throughout the paper. 
such as testing for stationarity, causation and endoegeneity (Khan and Qayyum 2007; Ghani and Ud-Din 2006; Atique et al 2004; Ud-Din et al 2003; Ahmad et al 2003) and has expanded its range of possible explanatory variables. This literature remains problematic.

Many theoretically important causes of growth are notoriously difficult to measure, and have consequently yielded inconclusive results. For example, 'government intervention' is typically measured using crude proxy variables such as 'government consumption' or 'the budget deficit', and these show no clear relation with GDP growth in Pakistan (Ghani and Ud-Din, 2006; Iqbal and Zahid, 1998; Tahir, 1995). Any causal link may be hard to identify using econometric analysis because government policy interventions are not random in Pakistan (Rodrik 2005). For example in the 2009-10 budget the government of Pakistan respond to political pressures to increase import tariffs during a recession to help domestic industry and compensate for declining tax revenues. This policy will help generate a spurious relation between negative GDP growth and import tariffs. Econometrics has a generally recognised difficulty in identifying the causal mechanisms through which policies impact on economic growth. In Pakistan, for example, during the 1950s and 1960s, an overvalued exchange rate and import tariffs made investment in manufacturing very profitable; during the 1970 s, there were big increases in public investment; during the 1980s, investment was favoured with tax cuts and tariff rebates; and during the 1990s the financial sector was liberalised with the intention of increasing the effectiveness of investment. Even with strong evidence that investment is important econometric research contributes very little in explaining which of these circumstances was best for promoting investment, and why.

The second methodology has been to divide the period in Pakistan since independence into case study periods and to analyse the processes and causes of economic growth in each. Case studies allow much greater attention to the complex causal mechanisms that influence growth (Gerring, 2007). For example, sharp increases in public investment under Zulfikar Bhutto in the 1970s provided both infrastructure and cheap inputs to industry. This should have relieved the constraints on industrial growth that had been widely noted by the late 1960s but there was no increase in economic growth. A case study approach can explain this paradox. The 1970s saw a series of political acts against the corporate sector that undermined the confidence of investors, and led to a collapse in private investment that offset the growth benefits of higher public investment (McCartney, 2011a:153). In the literature on Pakistan, case studies have usually been chosen to encompass particular political regimes. These periods are typically the chaotic democracy 1947-58, the military dictatorship of Ayub Khan 1958-68, the rise and fall of Bhutto 1971-77, the military dictatorship of Zia 1977-88, the return of democracy 1988-99, the military dictatorship of Musharraf 1999-2008 and the return (again) of democracy after 2008. There has little effort to select case studies according to any rigorous criteria based on either growth or its hypothesised causes (Gerring, 2007:86-150). An original contribution of this paper is to use a formal statistical method to select case study periods in Pakistan.

\section{Case studies of growth and stagnation: 1950-51 to 2011-12}




\subsection{The growth and stagnation literature}

This section begins by outlining how case study periods were selected for this research. This method draws on a recent body of work which finds that growth in developing countries is best characterised as occurring in episodes of growth and stagnation. Hausmann et al (2004) define an episode of growth as an increase in per capita growth of $2 \%+$ that is sustained for at least eight years and that the postacceleration growth rate has to be at least $3.5 \%$. To rule out cases of pure recovery the post-acceleration output has to exceed the pre-episode peak level of income. They find 83 growth accelerations in 110 countries between 1957 and 1992. This paper inspired a growing body of work that has since varied the definitions of acceleration and stagnation, the dataset and time period covered (Jerzmanowski 2006; Jones and Olken 2008; Cuberes and Jerzmanowski 2009; Jong-a-Pin and De Haan 2011; Berg et al 2012).

\subsection{Growth and Stagnation in Pakistan}

Inspired by this literature but focusing on a single country we distinguish case studies of growth and stagnation in Pakistan using a method based on the Chow Test (Chow, 1960). This test involves estimating an equation for the dependent variable and assessing the significance of a dummy variable that is 0 for all years before a candidate boundary year and 1 for all years after. If the dummy variable is found to be statistically significant it can be concluded that there has been a structural break in growth in that year. The procedure introduced by Quandt (1960) and refined by Andrews (1993), involves estimating T-1 equations, where $\mathrm{T}$ is the sample size, and calculating T-1 F-statistics corresponding to the significance of T-1 dummy variables. The largest of these F-statistics is then used in a Quandt-Andrews test. The test has a null hypothesis of no significant structural breaks in the sample. Once a first structural break year has been identified using this procedure, the same test can be used to look for others in the subsamples after it. To be sure of finding all relevant boundary years, the process is repeated until the test indicates no further significant structural breaks in the periods between the boundary years identified (Wallack, 2003:4312).

The equation we used to apply the Quandt-Andrews procedure to economic growth in Pakistan.

$$
G_{t}=\beta_{0}+\beta_{1} D_{t t^{\prime}}+\beta_{2} O_{1953-54}+\varepsilon_{t}
$$

$t$ - the current year

$G_{t}$-economic growth rate.

$D_{t t^{\prime}}$ - dummy variable to identify a step-change in economic growth in period $t^{\prime}$, value 1 if $t>t^{\prime}, 0$ otherwise.

$O_{1953-54}$ - one-period outlier dummy for 1953-54 when economic growth was high due to an export boom in jute and other raw materials used to supply the Korean War (Noman, 1988:20). 
The equation does not include lagged growth rates or a deterministic trend as these were tested and found insignificant in early versions of the model.

The equation was estimated using data on real GDP growth published by the State Bank of Pakistan (2010, 2012). The Quandt-Andrews test was applied repeatedly until there were no further significant structural breaks in economic growth. Figure 1 reports years with the highest F-statistic in different samples and the results of the Quandt-Andrews test. The top row is based on the whole sample, and rows 2 through 4 on subsequent subsamples. Figure 2 shows the case study periods that the boundary years separate. It superimposes the boundary years, marked by vertical dashed lines, on raw and smoothed real GDP growth data.

Figure 1: Quandt-Andrews test for real GDP growth

\begin{tabular}{lccc} 
Sample & $\begin{array}{l}\text { Year of maximum } \\
\text { F-statistic }\end{array}$ & $\begin{array}{l}\text { Maximum } \\
\text { F-statistic }\end{array}$ & $\begin{array}{l}\text { Quandt Andrews test } \\
\text { P-value }\end{array}$ \\
\hline 1950-51 to 2011-12 & $1960-61$ & 14.33 & $0.003 * * *$ \\
$1960-61$ to 2010-11 & $1992-93$ & 8.75 & $0.047 * *$ \\
$1992-93$ to 2010-11 & $2003-04$ & 2.46 & 0.674 \\
$1960-61$ to $1992-93$ & $1970-71$ & 2.90 & 0.570
\end{tabular}

Source: Author calculations based on State Bank of Pakistan (2010, 2012).

Notes: P-values calculated using Hansen's (1997) method; ** Denotes statistical significance at 5\% level; *** Denotes statistical significance at $1 \%$ level.

Figure 2: Real GDP growth, and dates of significant structural breaks, 1950-51 to 2010-11

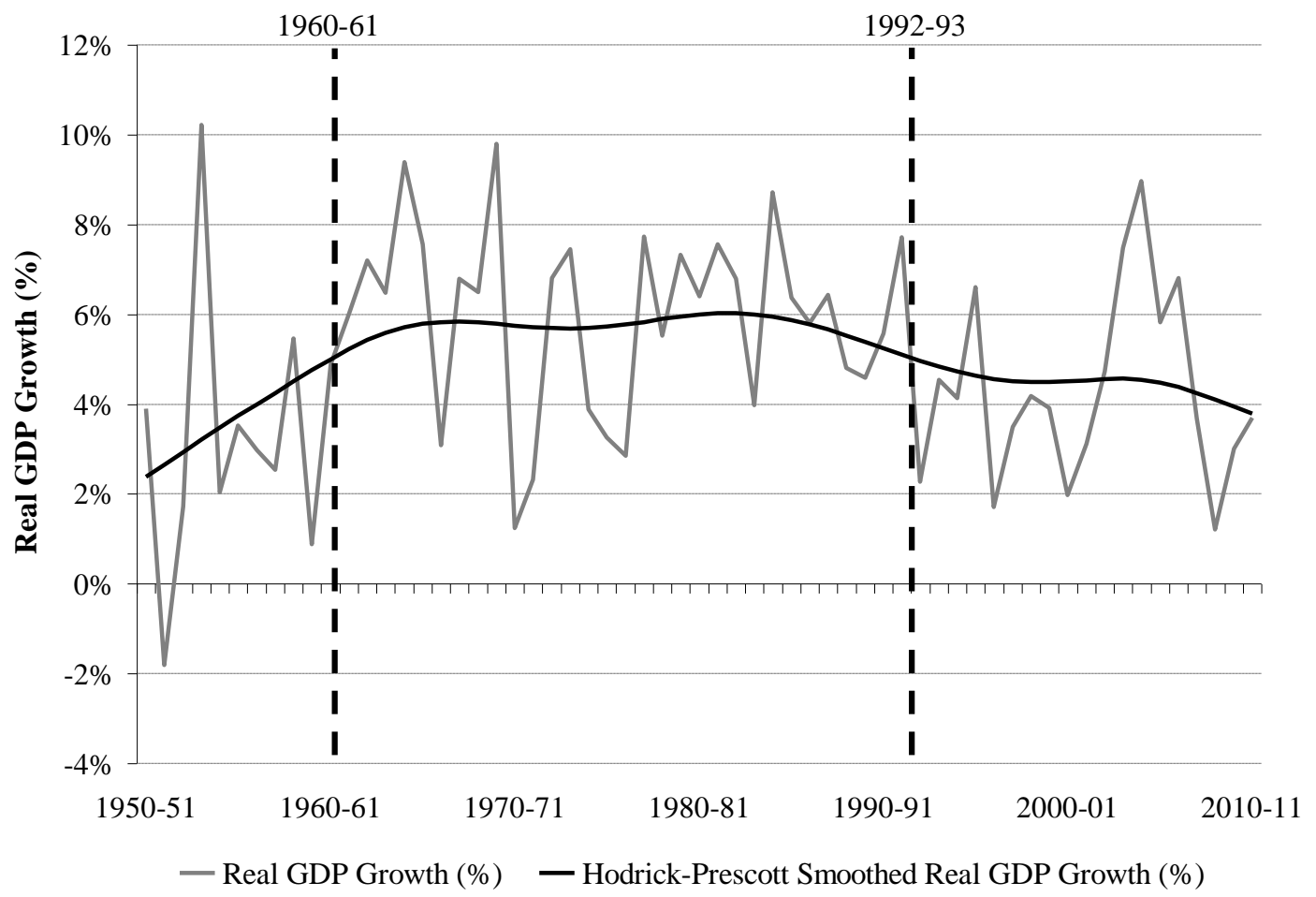

Source: State Bank of Pakistan (2010, 2012).

Notes: Hodrick Prescott filter uses $\lambda=100$ 
Figure 1 shows that there are significant structural breaks in economic growth in 1960-61 and 1992-93. The first episode of growth lasts from 1950-51 until 1960-61. This episode saw an increasing trend in real economic growth and an average rate of $3.1 \%$. The second covers a period of 32 years during which the economic growth rate was, on average, $6.0 \%$, with no major trend either up or down. Finally, the third from 1992-93 to 2010-11 saw an average rate of economic growth of $4.3 \%$ and a declining trend which continued to 2011-12.

Together, Figures 1 and 2 show that during the first 42 years of the sample period, Pakistan enjoyed considerable success in terms of economic growth, but thereafter relative economic failure. Over the first two episodes of growth there was an acceleration in economic growth which was sustained for 32 years. This is a very favourable performance when compared to the experience of other developing countries. Hausmann et al showed that 'very few' countries who achieved their definition of 'growth acceleration' (a $2 \%$ improvement in the growth rate) were able to sustain that acceleration over several decades (2004:1). This implies that Pakistan's success in achieving acceleration and then sustaining 6\% growth for three decades is exceptional. The thirty-two years of this rapid and sustained economic growth came to an end in 1992-93 and relative stagnation continued until at least 2011-12.

\section{Causes of both fast and slow growth in the three case study periods}

This paper is a companion piece to McCartney (2011b) which examined whether GDP growth in Pakistan since independence has been primarily driven by externalglobal factors or by the dynamics of the domestic economy. The paper found in favour of the latter hypothesis. This paper now draws from the literature on growth and stagnation to propose a hypothesis to help us look within the domestic economy to explore those dynamics in more detail.

\subsection{The Theoretical Model: Pro-market vs pro-business}

The key features of a pro-market strategy are that it supports new entrants and consumers. A pro-market strategy is based on the proposition that the free operation of markets will lead to a more efficient allocation of resources, promote competitiveness and so boost economic growth. Profits are likely to decline in a promarket strategy through the entry of new firms and greater competition between incumbents, new entrants, and foreign imports. By contrast pro-business economic policies include measures to boost the profits of incumbents, such as reductions in controls on entering sectors reserved for the public sector or on production capacity constraints or on the flow of credit from publicly controlled banks. Other policies may include public investment in infrastructure such as energy and transport and also efforts to keep labour costs low through weakening trade unions. On the demand side pro-business policies include expansionary fiscal and monetary policies and interventions (such as subsidies) to promote exports and investment (Kohli 2006). Under a pro-business strategy there is likely to be little new entry or churning in the corporate sector. The pro-business theory draws from the writings of the 
developmental state theorists who argued that economic growth in countries such as South Korea was promoted by states that prioritised economic growth, ruthlessly supported capitalists and repressed labour (Amsden 1989; Wade 1990). The key aspects of a pro-market strategy that will be discussed in the context of our Pakistan case studies are competition, liberalisation of markets and new entry and those of a pro-business strategy are profits, labour repression, public investment, the allocation of credit and benefits going to incumbents.

\subsection{The Episodes of Growth and Stagnation Literature}

The general growth and stagnation literature discussed in section 3.1. finds support for both the pro-market and pro-business theoretical perspectives as outlined in section 4.1. Echoing Barro (1991) the growth and stagnation literature again finds that investment is important in explaining structural breaks in growth. Hausman et al (2004) find that growth accelerations are correlated with increases in the investment rate. Jones and Olken (2008) find that episodes of stagnation are associated with larger decreases in the growth rate of investment. Berg et al (2012) find that an improvement in investor protection (using measures of institutional quality) will increase the expected duration of a growth spell. The alternative hypothesis revolves around the orthodox view in economics that open markets are the best way to promote economic growth. Here there is some disagreement in the episodes literature.

Hausmann et al (2004) find that $85.5 \%$ of growth accelerations were not preceded or accompanied by liberalisations, and only $18.2 \%$ of liberalisations were followed by an episode of faster growth. By contrast Jong-a-Pin and De Haan (2011) find that growth accelerations are preceded by economic liberalisation and Berg et al (2012) find that trade liberalisation is both associated with initiating growth and also with sustaining growth.

These theoretical perspectives have been extensively debated in the Indian context seeking to explain the increase in GDP growth rates that occurred in c1980. Some argue in favour of the pro-market hypothesis (Panagariya 2004; Alfaro and Chari 2013) and others in favour of the pro-business hypothesis (Kohli 2006, 2012; Cali et al (2011). There has been little if any attempt to contrast these competing hypotheses for the case of Pakistan.

\section{1950-51 to 1960-61: The construction of a pro-business policy framework}

\subsection{Pro-market policies?}

There is no evidence that pro-market policies can explain the episode of growth in Pakistan after 1950-51. After the Korean War commodity price boom in 1952 export prices of jute and cotton fell sharply and the government responded by controlling imports through the use of detailed physical and exchange controls (the currency was not devalued). The share of private imports subject to licenses reached a peak of $94 \%$ in 1958/59 (Naqvi 1966). Tariffs were increased to high levels (Lewis 1969:72, 
1970:68) with rates on luxury goods ranging from 100\% to 300\% (Radhu 1964). The overvalued exchange rate combined with tariff protection turned the terms of trade against agriculture and in favour of manufacturing.

\subsection{Profits}

Policy was targeted towards boosting the profitability of manufacturing. The overvalued currency reduced the cost of imported capital machinery (Zaidi, 2005:92). By 1954-55 effective rates of protection (ERP) in Pakistan were 76 percent for consumer goods and 71 percent for intermediate goods (Lewis, 1969:134). These high tariff rates prevented the overvalued currency reducing the price of imported manufactured goods and threatening local production. Local producers were instead able to charge high prices (Islam, 1970:59). Costs of production in industry were kept down through very low or zero import duties on capital goods and raw materials. This trade policy combined with other tax incentives meant that by the early 1960s the market cost of capital was only $25-33 \%$ of its world price (Guisinger and Kazi 1978:394). Export duties on raw wool and cotton, cement, rice, fish, bamboo, hides and skin, jute, and tea were used throughout the 1950s (Radhu 1964). Since most agricultural exports were sold in highly competitive international markets the impact of these duties was to lower prices for Pakistani industry using them as inputs.

These policies were evident in the very high rates of profit in manufacturing. By the middle of the 1950s, profit rates of 50 to $100 \%$ were not uncommon, and by the end of the 1950s they were still in the range of 20 to 50\% (Papanek, 1967). These profits were subject to rates of corporation tax that varied between 50 and $60 \%$ but there were many exemptions such as tax holidays for certain types of businesses, backward areas of the country and accelerated depreciation allowances. Tax holidays alone accounted for approximately 50\% of corporate income tax receipts (Lewis 1970:135).

\subsection{Labour}

Soon after independence the government of Pakistan formed the All Pakistan Confederation of Labour (APCOL) as a state controlled labour organisation to isolate leftist influenced unions. The leader of APCOL was appointed Labour Minister in the Central Government. Alongside incorporation the government also resorted to cruder tactics and arrested leftist union leaders for fomenting strike activity and communist subversion. In 1954 the Communist Party and the rival PTUF union were banned (Shaheed 1983). At independence unions in Pakistan were weak and in most cases had only been branches of all-India organisations. The union system fragmented. between 1951 and 1958 the number of registered unions doubled from 309 to 635 while the total membership declined from 393,137 to 376,029 (Ahmed and Amjad 1984). The number of workers involved in disputes and days lost to those disputes increased from the late 1940s to a fairly low plateau between 1954 and 1958 (with a drop in 1955) (Wizarat 2002:231). The share of wages remained well below $40 \%$ of output per worker in manufacturing in 1959-60 (Ul Huq 1966:107).

\subsection{Public Investment}


Figure 3 showed that public investment increased from 1.6 to $7.3 \%$ of GDP over the 1950s. By the end of the 1950s, this investment brought, amongst other things, an almost doubling in hydroelectric power availability, an increase in railway track to reach 8,574 km, a 33 percent increase in port capacity in Karachi, and a fourfold increase in the number of telephones (Hasen, 1998:107; Husain, 1999).

\subsection{Allocation of credit}

Two new development finance banks, the Pakistan Industrial Credit and Investment Corporation (PICIC) and Pakistan Industrial Finance Corporation (PIFCO) were established to provide credit on favourable terms to would-be industrialists. The Pakistan Industrial Development Corporation (PIDC) was created to initiate investment in important industries where the necessary start-up capital exceeded that available to any private investor, or where there was a long gestation between investment and profitable operation. These industries were later sold at favourable prices to private industrialists (Zaidi, 2005:96).

\subsection{Incumbents Benefit}

There was a clear class of incumbents who benefited from, and responded to, these policies. At partition most private businesses in Karachi were owned by Hindus, Parsees and some Goanese Christians. By 1959 migrant groups with pre-partition experience in trade had settled in and around Karachi and taken over much of this business. These families included Dawood (engineering), Adamjee (trading, match factory), Saigol (rubber shoes and Kohinoor textile mills), Chinoy (chemical industry), and Haroon (sugar traders, and Moti (sugar mills). By 1954 the ruling Muslim League party was dominated by these migrant groups (Burki 1999:28-30. By the early 1960s these families were 'heavily represented' on the board of the PICIC and over the 1950s nearly half of PICIC loans went to this group of families (White 1974). Those industries set up by the PIDC were also sold to them (Zaidi 2005:96).

\subsection{Investment and Growth}

Together these measures encouraged investment by the private sector, particularly in the manufacturing of consumer goods. Figure 3 shows that total, public and private investment all increased over the 1950s. Between 1950-51 and 1960-61, GDP growth in Pakistan averaged 3.1\% p.a. and fluctuated around an increasing trend (see Figure 2).

Figure 3: Fixed investment in West Pakistan 1949-50 to 1959-60, \% of GDP 


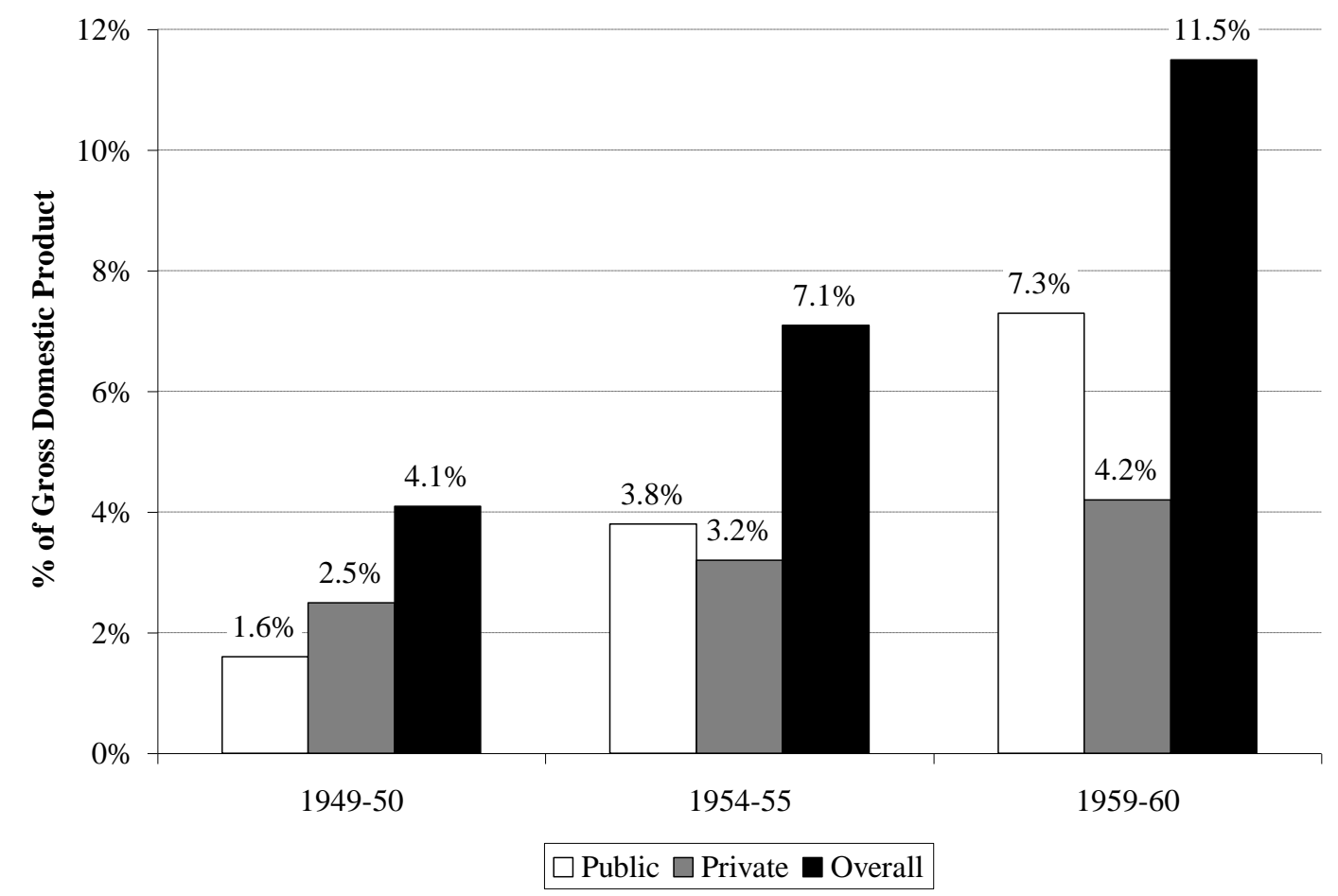

Source: Hasen (1998:108).

\section{1961-62 to 1991-92: The Travails of Alliances}

\subsection{Pro-Market Policies}

Some scholars see a more pro-market policy environment as being the cause of this faster economic growth - in particular, that the Free List and Export Bonus System (EBS) marked a shift from direct to more flexible and market-oriented controls (Papanek 1967:127). The Free List gave duty free import access to industrial raw materials and spare parts and was heralded as the "greatest step forward toward import liberalisation taken since the imposition of detailed licensing in 1953" (Thomas 1966:516). These pro-market benefits (which in any case occurred several years after the breakpoint in growth in c1960) were soon over. US and other foreign aid was cut back after the September 1965 war with India and the resulting decline in foreign exchange availability led to renewed controls on imports (Amjad 1982). Between 1959/60 and 1965/66 import tariffs increased from 35\% to $70 \%$ on essential consumer goods, from $99 \%$ to $180 \%$ on luxury consumer goods, from $81 \%$ to $114 \%$ on capital goods, and from $14 \%$ to $34 \%$ on machinery and equipment (Lewis, 1965:474, 1970:68; Thomas, 1966:532). The pro-market measures of the early 1960s did not reduce the anti-export bias of the effective exchange rate (Mahmood and Qasim, 1992:885). There were also tighter controls on access to trade credit after July 1964 (Thomas, 1966:518). The Export Bonus System (EBS) was introduced in 1959 and permitted exporters of manufactured goods to retain a portion of their foreign exchange earnings in the form of bonus vouchers. These vouchers could be used to purchase imports on the bonus-import list or be freely marketed at a large premium. Officials no longer had to determine who got an import license and for what 
commodity. The EBS did not though represent a shift to a more market oriented system. The lists of commodities on which a bonus was allowed, the number of commodities that could be imported under the scheme, and the rates of bonus were all determined by administrative decisions and were changed frequently.

The Bhutto era often associated with a big increase in state intervention, also contained important pro-market measures. Between 1971/72 and 1975/76 the Pakistani rupee was devalued by $130 \%$, import restrictions were abolished for over 300 commodity items, the EBS was abolished, and tariff rates were lowered on intermediate and capital goods. The trade bias index (effective exchange rate for imports divided by the effective exchange rate for exports) declined (Mahmood and Qasim 1992:885). Bhutto's government was not anti-private property per se - it was rather particular capitalists who fuelled its ire. Those capitalists that were expropriated were given generous compensation. The Habibs received Rs 36.31 for each share originally valued at Rs5. Nationalisation did not touch foreign capital. In 1976 the National Assembly passed a law (the first in Pakistan's history) exempting foreign capital from future nationalisation (Ahmed, 1982:110).

The political change in 1977 saw a 'comeback' of the private sector, if not unambiguous pro-market policies (Ahmad and Amjad, 1984). Policies included the denationalisation of some agro-based industries and small engineering units, protection of the rights of investors, opening certain heavy and basic chemical and cement industries to private sector investment, and incentives for private investors (tax holidays, reduced import duties and income taxes, the setting up of EPZs, and reduced interest rates for industrial investment). It is easy to exaggerate the degree of the shift towards pro-market policies. There was a sharp increase in the share of the public sector in non-agricultural GDP from 6.6\% in 1970/71 to $11.5 \%$ in $1974 / 75$; under Zia there was actually a slower increase to $13.7 \%$ by $1987 / 88$. The share of government in trade increased from $7.9 \%$ in 1974/75 to $30.2 \%$ in 1987/88 (Naqvi and Kemal 1991:111). By the mid-1980s Pakistan was still a relatively heavily protected economy with $31.6 \%$ of its exports facing tariffs of between $10 \%$ and $50 \%$, and $22.5 \%$ over $50 \%$ (James and Naya, 1990:213). Despite the opening of the non-bank financial sector for private investment in the mid-1980s, by 1990 the public sector financial institutions still held $74.7 \%$ of assets, $65.9 \%$ of advances and $93.8 \%$ of investments (Khan et al, 2005:822). Further steps towards more pro-market policies were initiated during the Sixth Five-year Plan (1983-88). The scope of investment licensing and tariffs on raw materials, intermediate goods, and capital goods was reduced. Some quantitative restrictions on imports were replaced by tariffs. The average level of tariffs was reduced, from $70 \%$ in 1979 to $30 \%$ in the late 1980s. Again, this shift was limited in its effects. Between 1976/77 and 1987/88 the rupee again became overvalued (it was pegged to an appreciating dollar), different duty rates were imposed for commercial and industrial users, and other quantitative restrictions on imports and export subsidies were extended. The trade bias index was actually higher in 1987/88 than it had been in 1976/77 (Mahmood and Qasim 1992:885).

\subsection{Profits}


During the 1960s trade policy continued to support industrial profits. Protection against imports was so extensive that by 1964, prices of imported manufactured goods were 50 to $60 \%$ higher than their domestic cost (Pal, 1964). The EBS allowed incumbent exporters buying capital equipment from abroad to purchase foreign exchange at a preferential exchange rate (Hasen, 1998:160). This in turn provided the investor with the opportunity of over-invoicing the cost of machinery then remitting the foreign exchange at the market rate (Griffin and Khan, 1972; Amjad, 1982). The typical magnitude of over-invoicing in 1966 was $10 \%$ and by 1970 this had increased to $20 \%$ (Winston, 1972). The 'effective subsidy' can be defined as the percentage of value added in industry due to the multiple pricing of foreign exchange for inputs and outputs. In 1963/64 effective subsidy rates were $88 \%$ in cotton textiles, $46 \%$ in footwear, $80 \%$ in jute textiles, $85 \%$ in leather tanning, $58 \%$ in sewing machinery, and $48 \%$ in sports goods (Lewis 1970:130).

Annual profits of 50-100\% in the early 1950s slowly declined to still high levels in the 1960s (Papanek, 1967:33, 39). Amjad measured the weighted average of profitability for companies quoted on the Karachi Stock Exchange (KSE) in 1961-65 and 1966-70 (excluding 1967). He found that they declined from 23.1 to $21.2 \%$ for gross profits (minus net worth) divided by net worth, from 21.1 to $17.3 \%$ for gross profits divided by net assets, and from 17.9 to $15.8 \%$ for the price-cost margin (1982:67). These patterns in profitability were heavily influenced by government intervention, in particular the variation in the bonus rate on the EBS for cotton textiles (1982:70). There is good evidence that a large fraction of these profits were reinvested (Haq and Baqai, 1967; White, 1974). While corporations faced a nominal tax rate that varied between 50 and $60 \%$ there were many exemptions such as tax holidays for certain types of businesses and geographic areas of the country and accelerated depreciation allowances. In total less than about $30 \%$ of corporate profits were taxed. In 1964/65 legally recognised accumulated tax arrears were twice as large as direct tax payments and only $75 \%$ of the direct taxes assessed that year were actually paid (Papanek, 1967:193; White, 1974:164; Amjad, 1982:35).

The abolition of the EBS and massive (131\%) devaluation of the Pakistani rupee in 1977 removed many of those props to industrial profits (Zaidi, 2005:105). The prolabour tilt of the early Bhutto government resulted in real wage increases, strikes, and, in large-scale manufacturing, a 6 percentage point increase in the share of wages relative to profits (Qureshi and Bilqueez, 1977:331). After Bhutto's fall from power, bringing 'the private sector back into partnership with the government to help with the country's economic growth' was given as the main objective for the 1978-83 Five-year Plan under the Zia government (Burki and Baxter, 1991:100,105). The probusiness policies during the 1980s were similar to those of the high growth 1960s. As in the 1960s, domestic markets were protected from import competition (Hasen, 1998:243). After 1978 new investors received reduced interest rates and tax holidays and rice husking, flour milling and cotton ginning mills had been de-nationalised. Although there was no return to the EBS of the 1960s, starting in 1982 manufactured exports were incentivised using exchange rate devaluation, tax rebates, and subsidies (Hasen, 1998:241).

\subsection{Labour}


In 1959 the military government of Ayub Khan passed the Industrial Disputes Ordinance, which declared many sectors to be either 'essential industries' (railways, post, telegraph, water, ports, defence, and telephones) or 'essential for the time being' (cement, iron and steel, sugar, leather and leather goods, vegetable oils, electrical equipment) in which strikes were forbidden. A Presidential Ordinance in March 1963 banned the publication of any news items relating to strikes or industrial unrest. The number of strikes fell drastically (Shaheed, 1983), and, likely as a result, real wages fell whilst hours worked increased (Khan, 1967:326, 331).

After the early 1960s government labour policy became more contradictory. The government established various Minimum Wage Boards in 1961 which increased wages of the least skilled in cotton textiles by 30\% (Guisinger and Irfan, 1974:374). Between 1962 and 1963 wages for civil servants were increased. This government lead undermined more general efforts to control wage levels in industry and trade unions began to push for comparable wage increases. In 1962 a successful strike in a Karachi tobacco company gave the labour movement the impetus to establish an alternative labour organisation, the Mazdoor Rabita (Workers Coordination) Committee. This undermined the government sponsored APCOL. The number of strikes that had fallen sharply during the early 1960s more than doubled between 1963 and 1964 (Ahmed and Amjad, 1984). In 1963 the Mazdoor Rabita had organised a large-scale strike in the textile sector. The strike met with initial success and an unprecedented promise of higher pay. Management later refused payment to all workers and in response faced more protest. The government responded by arresting 800 workers including all top leaders and forced labour to resume production. In 1964 with preparations being made for a general election trade unions were granted concessions in the form of increased wages and more favourable decisions in the Industrial Courts (Guisinger and Irfan, 1974; Shaheed, 1983). A renewed upsurge of strike activity in the late 1960s saw the number of person-days lost to disputes increase from 226,778 in 1967 to 1,220,377 in 1969 (Wizarat, 2002:231). This time the government responded more quickly with concessions and sought to improve labour conditions. The money wage of all production workers increased by $26 \%$ between 1967/68 and 1969/70 (Guisinger and Hicks, 1978:1276).

The Bhutto government in April 1972 granted workers greater participation in management, a right to a share in profits, easier rights to strike, and various other employer-provided benefits. In addition, a cost-of-living ordinance, which sought to ensure that wage increases matched inflation, was enacted (Ahmed and Amjad, 1984). This tilt towards labour was short-lived and the Bhutto government soon began to brutally supress strike activity, around 200,000 workdays were lost in 1973, this fell sharply to a few thousand by 1977 . The Zia government continued this stance and barring a small rise in strike activity connected with the movement to restore democracy in 1982 and 1983 work-days lost to strikes remained low until the early 1990s. A rapid growth in unionisation went into reverse in 1977 and both the number of unions and trade union membership fell steadily (Candland 2007).

\subsection{Public Investment}

During the 1960s public investment in West Pakistan fluctuated between 7 and $9 \%$ of GDP and in East Pakistan it rose from 3.5 to 7\% of GDP (Amjad 1982:18; Hasen, 
1998:147). This investment included large-scale infrastructure projects. The Tarbela dam, completed in 1971 proved to be a crucial asset as oil prices later increased rapidly and increased hydroelectric power capacity to 267 MW by 1964-65 (Hasen 1998). Installed thermal capacity rose from $39 \mathrm{MW}$ in 1959 to $560.5 \mathrm{MW}$ in 1965 (Husain, 1999).

State created credit institutions played an increasing role in allocating finance to private sector industry. Between 1960 and 1965 government authorisation for an investment project came with the ability to obtain the necessary foreign exchange from the PICIC or IDBP. PICIC and IDBP provided almost $70 \%$ of the foreign exchange component of total investment projects sanctioned and accounted for about $65 \%$ of total investment sanctioned during between 1960 and 1965, and $60 \%$ between 1965 and 1970 (Amjad, 1982:56). The number of bank branches increased from 1,298 in 1964 to 6,737 in 1977, then more slowly to 7,404 in 1990 (Zaidi, 2015:400). The Pakistan Industrial Development Corporation (PIDC) was a semi-autonomous government agency which pioneered investment in some industries where the necessary start-up capital exceeded that available to any private firm. By 1953/54 cumulative expenditures by PIDC had reached about $7 \%$ of total industrial assets and about 15\% by 1959 (Papanek, 1967:97).

Over the 1970s public investment in large-scale manufacturing increased rapidly to fill the gap left by private investors (see Figure 4), but it was not enough. Long gestating, capital-intensive public sector projects such as the Pakistan steel mill (Afridi, 1985:465; Nawab et al 1984:66) generated a construction boom in the first half of the 1970s (Hasen, 1998), but the positive relationship between public and private investments, which had been evident in earlier periods, no longer seemed to be working. As a result, growth in large-scale manufacturing collapsed from an average of $9.9 \%$ p.a. in the 1960 s to only $0.9 \%$ p.a. between $1973-74$ and 1976-77 (State Bank of Pakistan, 2012).

The 1980s also mirrored the 1960s as generous foreign aid was recycled by the government into credit on easy terms to key sectors, this time through the newly nationalised banking sector rather than through the state financial corporations (Sayeed, 2002).

\subsection{Incumbents Benefit}

There is evidence that these policies benefited a small group of elite incumbents, and that, in return, these incumbents reinvested their profits. Almost $65 \%$ of loans disbursed by the PICICI between 1958 and 1970 went to 37 monopoly houses, with 13 of the larger monopoly houses getting about 70\% of this amount (Amjad 1982:50). The IDBP was established in 1961 with a mandate to serve smaller investors though over $30 \%$ of its loans during the 1960 s went to 30 established monopoly houses (Amjad 1982:50). Over time many of the projects established by PIDC were sold to the private sector and played a crucial role in establishing some of the major industrial houses especially in East Pakistan. In West Pakistan Saigol bought the Jauharabad Sugar Mill and Dawoods took over the Burewala Textile Mills from the PIDC (Amjad 1983:237). At the end of the 1960s, Mahbub ul Haq, the chief economist of the Planning Commission announced that 22 families in West Pakistan owned 66 
percent of the country's industrial wealth and 75 percent of its banks (Rahman 2012:187). In West Pakistan in 1970 the top businesses were, with few exceptions, the same as those in 1961. Regression analysis shows that the number of capital goods licenses allocated to family businesses throughout the 1960s were positively related to the size of the assets they controlled in 1961 (White, 1974).

In 1972 the Bhutto government nationalised ten capital and intermediate goods sectors with cotton mills, banking, rice, and flour following in subsequent years (Ahmed and Amjad, 1984:92; Hasen, 1998:208-9). Dawood lost Karnaphuli Paper Mills, Karnaphuli Rayon, and Dawood Shipping. Adamjee lost six tea gardens in Sylhet and one of the biggest jute mills in Asia. Bawany lost Latif Bawany Jute Mills (Rahman 2012:210). By 1974, the left wing of Bhutto's party had been 'purged' and, as a result, genuine efforts to redistribute the wealth of the biggest business houses ceased (Noman, 1988:74, 79). Figure 4 shows that the damage done to the top businesses was quite limited. Net assets for the majority of the top 26 industrial families were unaffected by the nationalisation programme, and the remainder saw only small reductions. Nationalisation had little impact either on industrial concentration. In one study, the concentration ratio of 273 large-scale firms actually increased from 55.62\% in 1967 to $59.01 \%$ in 1970 and to $61.79 \%$ in 1973 (Sharwani, 1976).

Figure 4: The effect of nationalisation on the top 26 industrial families, by asset size 


\begin{tabular}{|c|c|c|c|}
\hline \multirow[b]{2}{*}{ Family } & \multicolumn{3}{|c|}{ Net Assets (Million Rupees) } \\
\hline & $\begin{array}{c}\text { Pre } \\
\text { Nationalisation }\end{array}$ & $\begin{array}{c}\text { Post } \\
\text { Nationalisation }\end{array}$ & Change \\
\hline Saigol & 529.8 & 165.3 & -364.5 \\
\hline Habib & 228 & 68.6 & -159.4 \\
\hline Dawood & 210.8 & 767.5 & 556.7 \\
\hline Crescent & 201.7 & 201.7 & 0 \\
\hline Adamjee & 201.3 & 146.3 & -55 \\
\hline Colony $(\mathrm{N})$ & 189.7 & 95.8 & -93.9 \\
\hline Valika & 183.5 & 62.2 & -121.3 \\
\hline Hoti & 148.6 & 148.6 & 0 \\
\hline Amins & 137.9 & 137.9 & 0 \\
\hline Wazir Ali & 102.6 & 87.6 & -15 \\
\hline Fancy & 102.4 & Missing & Missing \\
\hline Beco & 101 & Missing & Missing \\
\hline Hussain & 81.7 & 81.7 & 0 \\
\hline Colony (F) & 89.9 & 19.8 & -70.1 \\
\hline Ghandara & 79.9 & 25.8 & -54.1 \\
\hline Hyesons & 79.4 & 83.5 & 4.1 \\
\hline Zafar-ul-Ahsan & 77.2 & 22.1 & -55.1 \\
\hline Bawany & 69.3 & 69.3 & 0 \\
\hline Premier & 56.1 & 56.1 & 0 \\
\hline Nishat & 54.3 & 54.3 & 0 \\
\hline Gul Ahmed & 52.3 & 52.3 & 0 \\
\hline Arag & 50.1 & 50.1 & 0 \\
\hline Rahimtoola & 49.9 & 49.9 & 0 \\
\hline Noon & 48.8 & 48.8 & 0 \\
\hline Shahnawaz & 46 & 46 & 0 \\
\hline Monnoo & 45 & 45 & 0 \\
\hline
\end{tabular}

Source: Amjad (1976:254).

The 1980s saw an effort to restore the close link between the state and incumbent businesses. A number of public sector enterprises were denationalised and incentives for private investment were restored (Kemal et al., 2006:315; Zaidi, 2005:114). Many of the families who had dominated industry prior to the Bhutto era benefited from these measures though incentives were also extended to some new entrants with close ties to the government, such as the Chaudhrys of Gujarat and the Sharif group of Lahore (Sayeed, 2002). The government also revived the various forums and committees that had existed in the 1960s to bring businessmen back into the process of discussing and making economic policy (Burki and Baxter, 1991:13, 104). Figure 5 shows that there was much more churning after 1970 among the leading industrial groups. The top groups in 1970 show little similarity to those in 1990.

Figure 5: Leading Industrial Groups 1970 and 1990 by manufacturing assets, listed and unlisted

\begin{tabular}{|l|l|}
\hline 1970 & 1990 \\
\hline
\end{tabular}




\begin{tabular}{|l|l|}
\hline Dawood & Habib \\
\hline Saigol & Crescent \\
\hline Adamjee & Dawood \\
\hline Jalil & Saigol \\
\hline Shaikh & Wazir Ali \\
\hline Fancy & Nishat \\
\hline Valika & Sapphire \\
\hline Bawany & Lakson \\
\hline Crescent & Fazalsons \\
\hline Wazir Ali & Gandhara \\
\hline Ghandara & Dewan \\
\hline Ispahani & Bawany \\
\hline Habib & Adamjee \\
\hline Khyber & Al-Noor \\
\hline Nishat & Ghulam Farooq \\
\hline
\end{tabular}

Rahman 2012:219

\subsection{Investment and Economic Growth}

During the early 1970s "The private sector lost all trust in the government" (Noman, 1988:76) and, as shown in Figure 6, private investments in manufacturing collapsed.

Figure 6: Investment in large-scale manufacturing, 1969-70 to 1975-76

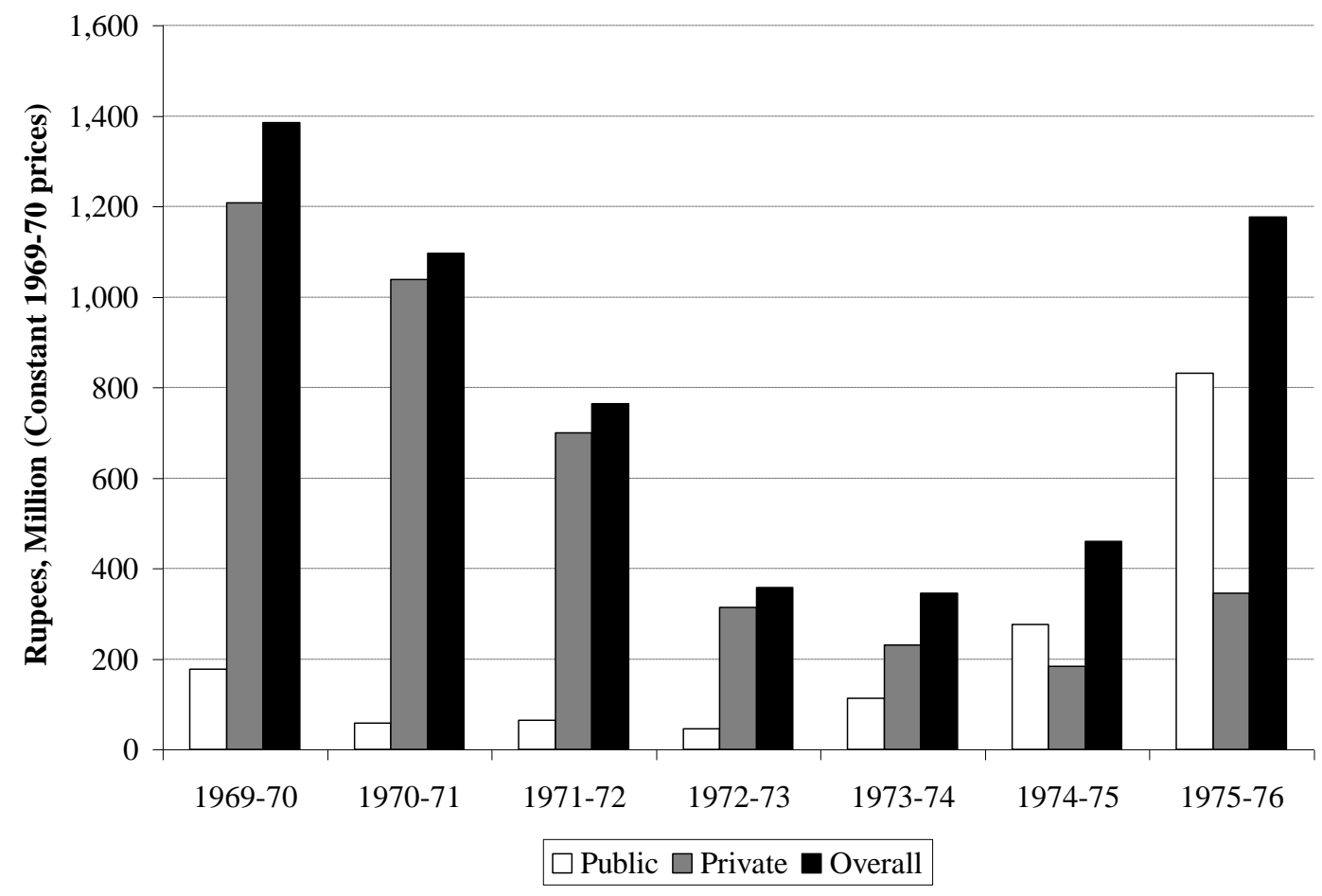

Source: Zaidi (2005:107).

With the effort to restore some pro-business policies after 1977 private investment in manufacturing grew by 15.6\% p.a. between 1977 and 1986 (Zaidi, 2005:118). 
Between 1961-62 and 1991-92 GDP growth averaged 6.0\% p.a. The smoothed GDP growth series in Figure 1 reveals that there were no major trends either up or down during this period though perhaps some indication of slightly higher growth at the beginning and end of this era and a somewhat slower growth in the middle years.

\section{1992-93 to 2011-12: Disaster}

\subsection{Pro-Market Policies?}

The episode of stagnation after 1992/93 was associated with the promise and practice of pro-market reforms. The acceptance of World Bank/ IMF-induced conditionality culminated in a three-year agreement scheduled to run from 1988 to 1991 and was reflected in the Seventh Five-year Plan (1988-93). Pro-market reforms included deregulation of business, phasing out industrial location policies, providing infrastructural facilities at economic costs, selling shares in public sector enterprises, and substantial trade liberalisation (Zaidi, 2005). The maximum tariff on imports was reduced from $225 \%$ in $1986 / 87$, to $70 \%$ in $1994 / 95$ and $25 \%$ in $2001 / 02$. The number of tariff slabs declined from 14 to 4 over the 1990s. The average tariff on dutiable imports (excluding duty-free imports) fell from 23\% in 1996-97 to 17\% in 2001/02. The rupee depreciated by about $10 \%$ annually against the dollar over the $1990 \mathrm{~s}$ (Anwar, 2000; Ud-Din et al, 2003; Zaidi, 2005). Pakistan's progress in trade liberalisation exceeded those requirements under the WTO (Anwar, 2000:8). These changes sought to increase competitive pressures on incumbents by easing the entry of new producers and by encouraging more imports. To allow the increased entry of competitors from abroad, restrictions on FDI were lifted and firms were permitted to bring in capital, send profits home, and issue shares. Foreign equity participation of up to 100\% was allowed for both new and existing enterprises (Kemal, 1999:156). The evidence shows that these measures were effective in making it easier for new competitors to enter markets. In 2010, Pakistan was ranked number 56 amongst 183 countries for ease of opening a business, by comparison India ranked 138 (World Bank, 2010).

\subsection{Profits}

Incumbent businesses experienced a sharp fall in profits as market competition undermined their privileged position. By the end of the 1990s for example most textile units operated at a loss and failed to declare any dividends (Khan, 1998:605). A survey in 2008 found that of 209 cotton and other textile firms listed on the Karachi Stock Exchange, only 69 were profitable and only 37 were paying dividends. Of 34 chemical and pharmaceutical firms, only 26 were profitable and 20 paying dividends. For the 37 sugar and allied manufacturers, the figures were 21 and 11, respectively (Government of Pakistan, 2010:174). In the newly privatised banking sector, there was also a fall in earnings. Returns on banking assets declined from $0.8 \%$ in 1992 to 0.0 percent in 2001; return on equity, with more extreme fluctuations, declined from $18.2 \%$ in 1992 to $-0.1 \%$ in 2001 (International Monetary Fund, 2002:51). 
There were some attempts during the early years of the Musharraf government to strengthen pro-business policies. For example, the state's 'Textile Vision Strategy $2005^{\prime}$ included many efforts to support the profits of incumbents and to direct credit towards them. The government established a separate Ministry of Textiles with the purpose of supporting the sector (Government of Pakistan, 2009:15). This ministry created a programme to reduce contamination in raw cotton and reduce tariffs on textile machinery imports; remove sales tax and import duties on raw materials; and provide assistance on textile-related research and development. In response, imports of textile machinery increased to \$928.6 million in 2004-05 (Government of Pakistan, 2010:46). Between 2002 and 2009, the number of cotton textile spindles increased from around 9.2 million to more than 10.5 million and total cloth production almost doubled from 576.6 (million square metres) to 1,019.2 (msm) (Government of Pakistan, 2010). More generally there was a significant improvement in the financial performance of the private corporate sector. Between 2001 and 2003, the after-tax profits of corporations listed on the Karachi Stock Exchange rose by $1 \%$ of GDP (Lorie and Iqbal, 2005).

Starting in the mid-2000s, however, attempts to strengthen pro-business policies were thwarted by conditions attached to International Monetary Fund structural adjustment lending. The government were forced to abandon the provision of concessional credit to export-oriented textile firms. There was a consequent fall in both incumbent profitability and public investment (Government of Pakistan, 2009:15).

\subsection{Labour}

The political leadership over the 1990s had seemed more sympathetic to trade unions and did announce a new minimum wage policy in 2001. In practice real wages increased by only $0.7 \%$ p.a. on average between 1990 and 2006 and even declined between 1999 and 2002. Real wages among the bottom 60\% of wage earners declined over this entire period. Real wages in manufacturing (including textiles) and construction relative to other sectors declined steadily between 1990-91 and 2006-07 (Irfan 2009). Real wage growth was though undermined by slow economic growth, a rising share of the population being of working age (the demographic dividend) and more competition from imports and new entrants that together undermined corporate profitability (and so ability to increase wages). The total number of registered trade unions reporting data decline from 1,763 in 1990 to 1,201 in 2002 and the membership of those reporting unions fell from 360,000 in 1990 to 247,000 in 2002. The number of person-days lost through industrial disputes fell rapidly from a peak of 583,000 in 1991 to 1,020 in 2004 (Irfan 2009:28). The minimum wage had little impact on wage setting. By 2005-06 survey evidence suggests that half of wage earners were earning less than the stipulated minimum (Irfan 2009:3).

\subsection{Public Investment}

Public investment remained at high levels (8-9\% of GDP) in the first half of the 1990s, then fell sharply from 1996/97 onwards, reaching only 4\% of GDP in 2003/04. There was a slight increase to $5.6 \%$ in $2006 / 07$ with the pro-business reforms of the Musharraf government, then a renewed decline to $3.0 \%$ by 2011/12 (Zaidi 2015:144). 
Public investment was forced down in response to trade liberalisation which contributed to a decline in federal government tax revenue from $21.6 \%$ of GDP in $1991 / 92$ to $13.2 \%$ of GDP in 2009/10 (Zaidi 2015:277). The statistical evidence suggests that these cuts in turn reduced private investment (Ahmed and Qayyam, 2007; Hyder, 2001; Naqvi, 2002). This squeeze was not due to military expenditure which fell from 6.5\% of GDP in 1992/93 to 3.3\% in 2003/04 (Zaidi 2015:308). There is also evidence that during the 1990s political pressures and corruption weakened the institutional capacity for public investment. For example, formal approval procedures were often bypassed for work, roads, and energy expenditures. As a result, the remaining smaller amount of spending on development projects proved considerably less productive. By the end of 1996 Rs 700 billion worth of questionable projects had been started when only Rs85-90 billion per year was available to complete them (McCartney 2011a:183).

\subsection{Allocation of Credit}

Beginning in 1989, pro-market reforms were also enacted in finance, and over the 1990s, these reforms abolished state-directed credit for key sectors and introduced a market-led system. The idea was that a shift away from state intervention, and towards a lightly regulated and privately owned banking sector, would bring both a market allocation of investible funds. In the early 1990s, three of the five nationalised banks were either privatised or sold. Between 1997 and 2001 the remaining partially privatised banks were fully privatised. The state finance corporations, were either closed or pushed into becoming regular banks, as happened with the PICIC (Husain, 2003; Zaidi, 2005). Licenses were granted to new and foreign banks. By 2003, 14 new domestic private commercial banks and 16 private investment banks had been established, and 19 foreign commercial banks were operating in the country (Husain, 2003). The number of private banks increased from 13 to 20 between 1993 and 2005 and the number of private branches increased from 284 to 4,189 . The number of state owned banks declined from 7 to 4 and the number of state owned branches fell from 7,058 to 1,575 (Irfan 2009:22). The new banking sector was given greater discretion over lending allocation as reserve requirements were reduced and subsidised credit schemes were cut back (Zaidi, 2005:123). The real interest rate for domestic business increased from $-0.3 \%$ between 1990-96 to $4.9 \%$ in 1996-99 and 9.9\% 1999/00 (Zaidi 2015:313).

\subsection{Incumbents Benefit}

The extent of the resulting churning in the corporate sector can be seen in figure 7 which shows the changes in the league table of leading industrial groups in 1990 and 1997.

Figure 7: Leading Industrial Groups 1990 and 1997 by manufacturing assets, listed and unlisted

\begin{tabular}{|l|l|}
\hline 1990 & 1997 \\
\hline Habib & Nishat \\
\hline Crescent & Saigol \\
\hline Dawood & Crescent \\
\hline
\end{tabular}




\begin{tabular}{|l|l|}
\hline Saigol & Dewan \\
\hline Wazir Ali & Ittefaq \\
\hline Nishat & Chakwal \\
\hline Sapphire & Habib \\
\hline Lakson & Sapphire/ Gulistan \\
\hline Fazalsons & Gul Ahmad/ Al-Karam \\
\hline Gandhara & Packages \\
\hline Dewan & Chakwal \\
\hline Bawany & Atlas \\
\hline Adamjee & Haswani \\
\hline Al-Noor & Bibojee-saifullah \\
\hline Ghulam Farooq & Dawood \\
\hline
\end{tabular}

Rahman 2012:219

\subsection{Investment and Economic Growth}

Total investment was 19\% of GDP in 1992-93 and stagnated throughout the 1990s at less than $15 \%$ of GDP then increased after 2002/03 to around $22 \%$ of GDP in 2006/07, thereafter it again fell rapidly to $11 \%$ of GDP by 2011/12 (World Bank, 2012). During the third case study period, 1992-93 to 2011-12 real GDP growth averaged only $4.3 \%$ p.a. and continued to decline throughout (Figure 2).

\section{Policy Implications}

If Pakistan is to engineer a return to fast growth, policy must move away from its promarket bias. The pro-market reforms of the 1990s were intended to utilise the pressures of more competition to generate gains in efficiency and productivity, but these indices either stagnated or declined over the 1990s and 2000s. The shift to a pro-market policy regime in the 1990s succeeded in rupturing the pro-business strategy that had previously supported incumbents' profits. In doing so, it reduced incentives for private investment in the corporate sector. Any future strategy must find a way to re-engineer strong positive incentives for investment, either by incumbents or new private investors in order to revive economic growth. This is not to say that the pro-business strategies of the past are a panacea for contemporary Pakistan. This paper has only focussed on economic growth and not on other objectives such as equality, health, and democracy. It must be acknowledged that Pakistan's earlier pattern of growth has been judged a failure on many of these counts.

This paper shows that what has brought success in terms of high growth over the long term is a judicious mix of government intervention and market forces chosen to incentivise private sector investment mainly by incumbents. The difficulty of bringing this vision to life in Pakistan has, however, revealed itself in stark clarity by the shortlived efforts by the Musharraf regime to promote rapid and inclusive growth. These efforts quickly dissipated in the face of political pressures at home and conditionality from foreign lenders. They were abandoned after 2004 in favour of a bout of fiscally irresponsible populism. 


\section{References}

Afridi, U. (1985) Dynamics of Change in Pakistan's Large Scale Manufacturing Sector. The Pakistan Development Review 24:3-4, 463-478.

Ahmad, M.H., S.Alam, and M.S.Butt (2003) Foreign Direct Investment, Exports and Domestic Output in Pakistan. The Pakistan Development Review 42:4, 715-723.

Ahmed, M (1982), 'Substitution Elasticties in the Large Scale Manufacturing Industries of Pakistan: A Comment', The Pakistan Development Review, 21:1, p7382.

Ahmed, V., and R.Amjad (1984) The Management of Pakistan's Economy, 1947-82. Oxford University Press.

Ahmed, I, and A. Qayyam (2007), Do Public Expenditure and Macroeconomic Uncertainty Matter to Private Investment? Evidence from Pakistan. The Pakistan Development Review 46:2, 145-161.

Alfaro, L and A.Chari (2013), 'Reforms and the Competitive Environment', in J.Bhagwati and A.Panagariya (2013), 'Reforms and Economic Transformation in India', New Delhi, Oxford University Press.

Amjad, R. (1976) A Study of Investment Behaviour in Pakistan, 1962-70. The Pakistan Development Review 15:2, 134-153.

Amjad, R. (1982) Private Industrial Investment in Pakistan 1960-1970. Cambridge, Cambridge University Press.

Amjad, R. (1983) Industrial Concentration and Economic Power. In H. Gardezi and J.Rashid (eds.) Pakistan: The Roots of Dictatorship: The Political Economy of a Praetorian State. London, Zed Press.

Amsden, A.H. (1989) Asia's Next Giant: South Korea and Late Industrialisation. Oxford, Oxford University Press.

Andrews, D. (1993), Tests for Parameter Instability and Structural Change with Unknown Change Point. Econometrica 61, 821-56.

Anwar, T. (2000) Impact of Globalisation and Liberalisation on Growth, Employment and Poverty: A Case Study of Pakistan. State Bank of Pakistan.

Atique, Z., M.H.Khan, and U.Azhar (2004) The Impact of FDI on Economic Growth under Foreign Trade Regimes: A Case Study of Pakistan. The Pakistan Development Review 43:4, 707-718.

Barro, R.J. (1991) Economic Growth in a Gross Section of Countries. Quarterly Journal of Economics 106:2, 407-443. 
Berg, A J.D.Ostry and J.Zettelmeyer (2011), 'What makes growth sustained', EBRD Working Paper No 133, London.

Brock, W.A., and S.N.Durlauf (2001) Growth Empirics and Reality: What Have We Learned from a Decade of Empirical Research on Growth? World Bank Economic Review 15:2,229-272.

Burki, S.J. (1999) Pakistan: Fifty Years of Nationhood, 3rd ed. Boulder, Westview Press.

Burki, S.J.,and C.Baxter (1991) Pakistan Under the Military: Eleven Years of Zia ulHaq. Boulder, Westview Press.

Cali, M S.Mitra and P.Purohit (2011), 'Measuring State-Business Relations Within Developing Countries: An Application to Indian States', Journal of International Development, 23, p394-419.

Candland, C (2007), 'Workers' Organisations in Pakistan: Why Not Role in Formal Politics', Critical Asian Studies, 39:1, p35-57.

Chow, G. (1960) Tests of Equality Between Sets of Coefficients in Two Linear Regressions. Econometrica 28:3, 591-605.

Cuberes, D and M.Jerzmanowski (2009), 'Democracy, Diversification and Growth Reversals', Economic Journal, 119, p1270-1302.

Gerring, J. (2007). Case Study Research: Principles and Practises. Cambridge University Press.

Ghani, E.,and M.ud-Din (2006)The Impact of Public Investment on Economic Growth in Pakistan. The Pakistan Development Review 45:1, 87-98.

Government of Pakistan (2009) Economic Survey 2008-09. Finance Division, Islamabad.

Government of Pakistan (2010) Economic Survey 2009-10, Finance Division, Islamabad.

Griffin, K and A.R.Khan (1972), 'Industry and Trade', in Griffin, K and A.R.Khan (Eds) (1972), 'Growth and Inequality in Pakistan', London, Macmillan Press.

Guisinger, S and N.L.Hicks (1978), 'Long-term Trends in Income Distribution in Pakistan', World Development, 6, p1271-1280.

Guisinger, S and M.Irfan (1974), 'Real Wages of Industrial Workers in Pakistan: 1954 to 1970', The Pakistan Development Review, 13:4, p363-388.

Guisinger, S.E., and S.Kazi (1978) The Rental Cost of Capital for the Manufacturing Sector - 1959/60 to 1970/71. The Pakistan Development Review 17:4, 385-407. 
Hansen, B. (1997) Approximate Asymptotic p-values for Structural Change Tests. Journal of Business and Economic Statistics 15:1, 60-67.

Hasen, P. (1998) Pakistan's Economy at the Crossroads: Past Policies and Present Imperatives. Karachi, Oxford University Press.

Haq, K., and M.Baqai (1967) Savings and Financial Flows in the Corporate Sector, 1959-63. The Pakistan Development Review 7:3, 283-316.

Hausmann, R., L.Pritchett, and D. Rodrik (2004) Growth Accelerations. Kennedy School of Government, Harvard University.

Husain, I. (1999) Pakistan: The Economy of an Elitist State. Oxford University Press.

Husain, I. (2003) Economic Management in Pakistan, 1999-2002. Oxford University Press.

Hyder, K. (2001) Crowding Out Hypothesis in a Vector Error Correction Framework: A Case Study of Pakistan. The Pakistan Development Review 40:4, 633-650.

International Monetary Fund (2002) Pakistan: Selected Issues and Statistical Appendix. International Money Fund.

Iqbal, Z., and G.M.Zahid (1998) Macroeconomic Determinants of Economic Growth in Pakistan. The Pakistan Development Review 37:2, 125-148.

Irfan, M (2009), 'Pakistan's Wage Structure during 1990-91 -2006-07', Pakistan Institute for Development Economics, Working Papers 2009:54, Islamabad.

Islam, N. (1970) Factor Intensities in Manufacturing Industries in Pakistan. The Pakistan Development Review 10:2, 147-173.

James, W.E and S.Naya (1990), 'Trade and Industrialisation Policies for an Accelerated Development in Pakistan', The Pakistan Development Review, 29:3, p201-222.

Jerzmanowski, M (2006), 'Empirics of hills, plateaus, mountains and plains: A Markov-switching approach to growth', Journal of Development Economics, 81, p357-385.

Jones, B.F and B.A.Olken (2008), 'The Anatomy of Start-Stop Growth', The Review of Economics and Statistics, 90:3, p582-587.

Jong-a-Pin, R and J.De Haan (2011), 'Political regime change, economic liberalization and growth accelerations', Public Choice, 146, p93-115.

Kemal, A. R. (1999) Patterns and Growth of |Pakistan's Industrial Sector. In A.R.Khan (ed.) Fifty Years of Pakistan's Economy: Traditional Topics and Contemporary Concerns. Karachi, Oxford University Press. 
Kemal, A.R., M. Ud-Din, and U. Qadir (2006) Economic Growth in Pakistan. In K.S.Parikh (ed.) Explaining Growth in South Asia. Oxford University Press.

Khan, A.R. (1967) What Has Been Happening to Real Wages in Pakistan. The Pakistan Development Review 7:3, 317-347.

Khan, M.A A.Qayyum and S.A.Sheikh (2005), 'Financial Development and Economic Growth', The Pakistan Development Review, 44:4, p819-837.

Khan, M.A., and A.Qayyum (2007). Trade Liberalisation, Financial Development and Economic Growth. Pakistan Institute of Development Economics, Working Paper No. 19, Islamabad.

Khan, N.Z. (1998).Textile Sector of Pakistan: The Challenge Beyond 2004.The Pakistan Development Review 37:4, 595-619.

Khan, S.U.K. (2005) Macro Determinants of Total Factor Productivity in Pakistan. State Bank of Pakistan Research Bulletin 2:2, 383-401.

Kohli, A. (2006) Politics of Economic Growth in India, Part I: The 1980s. Economic and Political Weekly, April 1, 1251-1259.

Kohli, A (2012), 'Poverty Amid Plenty in the New India', Cambridge, Cambridge University Press.

Levine, R., and D.Renelt (1992) A Sensitivity of Cross-Country Growth Regressions. American Economic Review 82:4, 942-963.

Lewis, S.R (1965), 'Domestic Resources and Fiscal Policy in Pakistans Second and Third Plans', Pakistan Development Review, 5;3, p461-495.

Lewis, S.R. (1969), 'Economic Policy and Industrial Growth in Pakistan', London, George Allen and Unwin Limited.

Lewis, S.R. (1970) Pakistan: Industrialisation and Trade Policies. London, Oxford University Press.

Lorie, H., and Z.Iqbal (2005) Pakistan's Macroeconomic Adjustment and Resumption of Growth, 1999-2004. IMF Working Paper, WP/05/139.

Mahmood, Z and M.A.Qasim (1992), 'Foreign Trade Regime and Savings in Pakistan', The Pakistan Development Review, 31:4, p883-893.

McCartney, M. (2011a) Pakistan-The Political Economy of Growth, Stagnation and the State-1951 to 2009. Routledge.

McCartney, M. (2011b) Pakistan, Growth, Dependency, and Crisis. The Lahore Journal of Economics 16 (Special Edition):71-94. 
Naqvi, N.H. (2002) Crowding Out or Crowding In? Modelling the Relationship between Public and Private Fixed Capital Formation Using Co-integration Analysis: The Case of Pakistan. The Pakistan Development Review 41:3, 255-275.

Naqvi, S.N.H (1966), 'The Allocative Biases of Pakistans Commercial Policy: 1953 to 1963', Pakistan Development Review, 6:4, p465-499.

Naqvi, S.N.H and A.R.Kemal (1991), 'Protectionism and Efficiency in Manufacturing: A Case Study of Pakistan’, San Francisco, ICS Press.

Nawab, S., H.Naqvi, and K.Sarmad (1984) Pakistan's Economy through the Seventies. Pakistan Institute of Development Economics.

Noman, O. (1988), 'The Political Economy of Pakistan, 1947-85', London, KPI.

Pal, M.L. (1964) The Determinants of the Domestic Prices of Imports. The Pakistan Development Review 4:4, 597-622.

Papanek, G.F. (1967), 'Pakistan's Development: Social Goals and Private Incentives', Cambridge, Harvard University Press.

Quandt, R. (1960), 'Tests of the Hypothesis that a Linear Regression Obeys Two Separate Regimes', Journal of the American Statistical Association, 55:324-330.

Qureshi, M.L., and F.Bilquees (1977), 'A Note on Changes in Real Wages of Government Servants 1959/60 to 1975/76/, The Pakistan Development Review, 16:3, 325-344.

Radhu, G.M. (1964) The Rate Structure of Indirect Taxes in Pakistan. The Pakistan Development Review 4:3, 527-551.

Rahman, T (2012), 'The Class Structure of Pakistan', Karachi, Oxford University Press.

Rodrik, D (2005), 'Why We Learn Nothing from Regressing Economic Growth on Policies'

Sayeed, A. (2002) State-Society Conjunctures and Disjunctures: Pakistans Manufacturing Performance. In S.M.Naseem and K.Nadvi (eds.), 'The Post-Colonial State and Social Transformation in India and Pakistan', Karachi, Oxford University Press.

Shaheed, Z.A. (1983) Role of Government in the Development of the Labour Movement. In H. Gardezi and J.Rashid (eds.) Pakistan: The Roots of Dictatorship: The Political Economy of a Praetorian State, Zed Press.

Sharwani, K. (1976) Some New Evidence on Concentration and Profitability in Pakistans Large-Scale Manufacturing Industries. The Pakistan Development Review $15: 3,272-289$. 
State Bank of Pakistan (2010) Handbook of Statistics on Pakistan Economy. http://www.sbp.org.pk/departments/stats/PakEconomy_HandBook/, accessed 16 February 2012.

State Bank of Pakistan (2012) State Bank of Pakistan Annual Report for 201011.http://www.sbp.org.pk/reports/annual/arFY11/Economic_Outlook.pdf, accessed 16 February 2012.

Tahir, R. (1995) Defence Spending and Economic Growth: Re-examining the Issue of Causality for Pakistan and India. The Pakistan Development Review 34:4, 1109-1117.

Thomas, P.S (1966), 'Import Licensing and Import Liberalisation in Pakistan', Pakistan Development Review, 6:4, p500-546.

Ud-Din, M., E. Ghani, and O.Siddique (2003). Openness and Economic Growth in Pakistan. Pakistan Development Review 42:4, 795-807.

U1 Haq, M (1966', 'The Strategy of Economic Planning', Karachi, Oxford University Press.

Wade, R. (1990), 'Governing the Market: Economic Theory and the Role of Government in East Asian Industrialisation', Princeton, Princeton University Press.

Wallack, J.S. (2003) Structural Breaks in Indian Macroeconomic Data. Economic and Political Weekly October 11:4312-4315.

White, L.J. (1974), 'Industrial Concentration and Economic Power in Pakistan', Princeton, Princeton University Press.

Winston, G.C (1970), 'Overinvoicing and Industrial Efficiency', in Griffin, K and A.R.Rahman (1972), 'Growth and Inequality in Pakistan', London, Macmillan Books.

Wizarat, S (2002), 'The Rise and Fall of Industrial Productivity in Pakistan', Karachi, Oxford University Press

World Bank (2010), 'Doing Business: Reforming Through Difficult Times', Washington, World Bank.

World Bank (2012), 'World Development Indicators 2012', Washington, World Bank.

Zaidi, S.A. (2005) Issues in Pakistan's Economy, $2^{\text {nd }} . e d$. Revised and expanded, Karachi, Oxford University Press.

Zaidi, A (2015), 'Issues in Pakistan's Economy: A Political Economy Perspective', $3^{\text {rd }}$.ed, Karachi, Oxford University Press 